\title{
ROLE AMBIGUITY AND JOB PERFORMANCE OF EMPLOYEES IN THE SERVICE SECTOR SMES IN MALAYSIA
}

\author{
SETHELA JUNE \\ ROSLI MAHMOOD \\ UUM College of Business \\ Universiti Utara Malaysia
}

\begin{abstract}
Small and medium size enterprises (SMEs) play a crucial role in the economic development of Malaysia, of which the majority are in the service sector. Employees of the service sector SMEs have often been associated with low level of job performance and past research has shown that there are many factors that can contribute to employee poor performance such as role ambiguity. Thus the aim of this study was to examine the relationship between role ambiguity and job performance of employees in the service sector SMEs in Malaysia. 1500 questionnaires were distributed and 300 were returned resulting in a $20 \%$ response rate. The result revealed that there was a significant relationship between role ambiguity and job performance of employees.
\end{abstract}

Keywords: SMEs, service sector SMEs, job performance, role ambiguity.

\section{Introduction}

Job performance of employees plays a crucial factor in determining an organisation's performance since highly performing individuals will be able to assist the organisation to achieve its strategic aims thus sustaining the organisation's competitive advantage (Lado \& Wilson, 1994; Dessler, 2011). At the same time, knowledge of employee job performance will allow managers to make various kinds of decisions ranging from compensation, promotion, and training as a basis for performance improvement to the extent of recommending termination (Piercy, Cravens \& Morgan, 1998). In addition, success in job performance is a gateway for reaping financial and nonfinancial rewards for employees (VanScotter, Motowidlo \& Cross, 2000). Nevertheless, Galagan (1997) expressed that given the many challenges that employees have to face due to the dynamism of the workplace, it is rather difficult for employees to maintain their job performance.

Moreover, employers tend to have high expectations concerning employee job performance by continuously monitoring the job performance of the employees through various performance management activities (Dessler, 2011). Thus, having a workforce that is well equipped with the right skills and is well prepared will ensure that business 
will not lose out due to the lack of ability to compete both nationally and internationally (Tomaka, 2001). SMEs in this context would not be alienated from similar circumstances. SMEs are regarded as critical especially when these businesses have been contributing to the growth and promoting the competitiveness of many nations (Caniel \& Romijn, 2005). This primary economic contribution made by the SMEs to a country had given rise to the interest for researchers to examine the various obstacles that hinder their progress (Alasadi \& Abdelrahim, 2008).

\section{Literature Review}

\section{SMEs in Malaysia}

SMEs in Malaysia are important in driving the Malaysian economy and its unemployment issues (Che Ros, Kumar \& Lim, 2006). Sustainable SMEs would be able to help in economic growth (SME Annual Report 2007), which in turn helps in job creation and generation of income and is always regarded as the backbone of the Malaysian economy (Ramayah \& Koay, 2002). While the SMEs sector plays an important role in Malaysia, it also faces many challenges. Although SMEs represent $99.2 \%$ of the total business establishments in Malaysia, the SMEs contribute only $32 \%$ to the GDP (SME Annual Report, 2007; Sin, 2010). This is lower than the average contribution in other Asian countries such as China and Japan in which the rate is over 50\% (Ndubisi, 2008; Osman, Ho \& Galang, 2011). Past studies about Malaysian SMEs have highlighted problems faced by Malaysian SMEs in general that have led to the Malaysian SMEs appearing to be less competitive (Saleh \& Ndubisi, 2006) and as hindrances that prevent good performance (Moha, 1999;
Hall, 2002; Stuti, 2005). In relation to this, skill shortages and productivity of employees have been highlighted as one of the on-going problems that dampens the progress of SMEs (SMIDEC, 2002; Wang, 2003; Ting, 2004; United Parcel Service, 2005; Saleh $\&$ Ndubisi, 2006) and found to be a serious problem in the majority of the SME firms surveyed in Malaysia (Yogeesvaran, 2005). Skills shortages is defined as the deficiency within the labour pool (Frogner, 2002) or deficiencies in the skills which employees need to carry out their existing tasks (Green, Machin \& Wilkinson, 1998).

With regards to the service sector in Malaysia, the majority of service firms in Malaysia are made up of those from the SME. Thus the service sector SMEs forms the largest sector of the SME establishments with a total of $86.5 \%$ of the total SME establishment (Department of Statistics, 2006). It generally includes the services, primary agriculture and information, and communication Technology (ICT). There are 2.2 million people employed in the service sector SMEs as compared to the manufacturing sector $(740,438)$ and the agriculture sector $(131,130)$ (Aris, 2007). Even though the service sector SMEs has the highest employment, the labour productivity of the manufacturing sector overtook the service sector SMEs at RM64, 089 while only RM47, 151 was contributed by the employees from the service sector (SME Annual Report, 2007). This supported the notion that job performance of employees in the service sector SMEs tend to be low due to lack of right skills (Saleh \& Ndubisi, 2006). Furthermore almost $72 \%$ of employment in the service sector SMEs were made up of those that possessed only Sijil Pelajaran Malaysia (SPM) qualification and below, which may affect the ability of the employees to deliver the expected standard of job performance due to lack of skills (Aris, 2007). 
Previous researches have shown that an individual level factor like role ambiguity (e.g. Jackson \& Schuler, 1985; Singh, 1993; Abramis, 1994; Bhuian, Menguc \& Borsboom, 2005; Murkherjee \& Maholtra, 2006; Lang, Thomas, Bliese \& Adler, 2007), may have an effect on employees' job performance. At the same time, employees working in a service setting have experienced role ambiguity (Wener, 1985; Singh \& Rhoads, 1991; Knowles, Grove \& Pickett, 1992; Price, Arnould \& Tierney, 1995; Babin \& Boles, 1998; Varca, 2002). In any service setting, employees who are able to understand and are clear about their roles in the organisation are likely to perform well in their jobs (Anderson, 2006). At the same time, past researches related to employees that work in a service setting (e.g. Murkherjee \& Maholtra, 2006; Lang, Thomas, Bliese \& Adler, 2007) have shown that role ambiguity influenced the employees' job performance. Furthermore, the outcome of past researches revealed either a negative, weak or no relationship between role ambiguities and job performance (e.g. Brief \& Aldag, 1976; Jackson \& Schuler, 1985; Michaels, Day \& Joachimsthaler, 1987; Singh, 1993; Beauchamp, Bray, Eys \& Carron, 2005; Hall, 2008).

Although past studies have shown that role ambiguity can affect the job performance of employees in the service setting, most of them were conducted abroad, thus very little evidence exists to understand the job performance of employees in the context of Malaysia.Furthermore, most SME researches in Malaysia focused on productivity and skill shortages (Yogeesvaran, 2005; Hamzah \& Ho, 1994; Tan, 1996; Saleh \& Ndubisi, 2006), entrepreneurial problems (Abdullah, Hamali, Deen, Saban \& Abdurahman, 2009), TQM and organizational performances (Sohail \& Hoong, 2003), empowerment (Wyer \& Mason, 1999), ICT adoption among SMEs (Alam \& Ahsan, 2007), SMEs historical development (Hashim, 2000), staff training and SMEs performance (Jamaludin \& Hasun, 2007) and assessment criteria of banks towards small business borrowers (Mahmood \& Rahman, 2007). Given such a situation, it necessitates this study to be carried out in view of the importance of the service sector SMEs in Malaysia. Therefore, the aim of this study is to investigate the relationship between role ambiguity and the job performance of employees working in the service sector SMEs in Malaysia.

\section{Job Performance: Conceptual, Theoretical and Empirical Review}

Job performance has always been regarded as an important factor in employee management and has commonly been defined as what a person does at work. Different stages of a job as well as the complexity of a job can affect the overall performance of the jobholder (Ackerman, 1997, Murphy, 1989). This could mean that job performance as a construct can be defined in different ways since it can be affected by the stage and complexity of the job (Grubb, 1999). It has been associated with the ability of the individual employees realizing their respective work goals, fulfilling expectations as well as attaining job targets and/or accomplishing standards that are set by their organizations (Eysenck, 1998; Mathis \& Jackson, 2000; Bohlander, Snell \& Sherman, 2001). The definitions of job performance are often unclear and hardly specific thus making them less useful (Campbell, Gasser \& Oswald, 1996).

Sarmiento and Beale (2007) referred to job performance as the result of two aspects, which consist of the abilities and skills (natural or acquired) of employees; and the motivation of employees to use their skills and abilities to perform a better job. 
According to Campbell, McCloy, Oppler and Sager (1993, p. 40), performance is "what the organization hires one to do, and do well". Campbell et al. (1993) further noted that only action that can be measured could be regarded as performance. Further, action was explained as that which is controllable and that which will be geared towards the organization's goal (Campbell et al., 1993). Even though many attempted to introduce various frameworks of performance, Campbell's definition of performance has been acceptable as the basic definition for performance (Borman, Hanson \& Hedge, 1997; Motowidlo, Borman \& Schmit, 1997; Schmitt \& Chan, 1998). Thus in synthesizing the above mentioned definitions, job performance is hereby defined as what an employee is expected to do in relation to job demand as when he or she is hired and covers only those actions or behaviours that are relevant to the organization's goals and measurable in terms of each individual's proficiency.

Campbell's (1990) Theory of Performance makes clear distinctions between performance components, performance determinants, and the antecedents of performance determinants. Performance components refer to the performance dimensions that constitute various parts of the overall job performance. Campbell posited that the performance component is a function of three performance determinants which are the declarative knowledge, procedural and skills knowledge and motivation (Campbell, 1990; Campbell et al.,1993). These are the direct determinants of performance, which is the focus of this paper. In detail, declarative knowledge includes knowledge about facts, principles, goals and self-knowledge, which represent an understanding of the requirements of a given task. Procedural and skills knowledge includes cognitive skills, psychomotor skills, physical skills, self- management skills, and interpersonal skills. Motivation is the combined effect of three choice behaviours: the choice to perform, the level of effort, and the persistence of the effort (Campbell et al., 1993). In other words, in order to perform the behaviours in one of the dimensions, a person needs to know what to do, how to do it and possess the desire to do it.

Past researches on job performance found several factors that can influence the employees' job performance ranging from individual-related factors, organizationallevel factors as well as organizationalenvironmental factors. For instance, employees' commitment has been found to affect job performance (Jaramilloa, Mulki \& Marshal, 2005; Al-Ahmadi, 2009). Besides that, job satisfaction was also found to have a significant relationship with employees' job performance (Gu \& Chi, 2009). In an attempt to determine the factors that influence the perceived job performance among the shopfloor employees, Sarmiento and Beale (2007) found no significant association between age and education among the employees while at the same time, education and job performance were found to have a negative relationship and this was further supported in a study by A-Ahmadi (2009). On the contrary the study by $\mathrm{Ng}$ and Feldman (2009), revealed differing results in which education was found to be positively related to employee job performance. Employees' self-efficacy, competitiveness and effort were also found to have a significant positive effect on the job performance of employees serving as front liners (Karatepe, Uludag, Menevis, Hadzimehmedagic \& Baddar, 2006). Selfefficacy and psychological climate were also found to be positively associated with the job performance of hospital employees in a study by D'Amato and Zijlstra (2008). Additionally, Knight, Kim and Crutsinger (2007), in their attempt to examine the 
causal relation between role stress, customer orientation, selling orientation, and job performance of retail salespeople, revealed that role conflict and role ambiguity affected customer orientation while affecting job performance when mediated by customer orientation.

\section{Role Ambiguity: Conceptual, Theoretical and Empirical Review}

Role ambiguity has been the study interest of many past researches related to human performance. Jackson and Schuler (1985) stressed the importance of having a clear understanding of one's role from an individual perspective as it is said to have an influence on one's motivation, satisfaction and performance. Furthermore role ambiguity can have various types of effects ranging from less psychological stress (Lang, Thomas, Bliese \& Adler, 2007), greater interests, innovation, self-actualization, autonomy, self-esteem, less tension, less physical stress and lower intention to leave (Ivancevich \& Donelly, 1974) and greater satisfaction (Busch \& Bush, 1978).

There were many attempts to delineate the meaning of role ambiguity. Ilgen and Hollenback (1991) define roles as the pattern of behaviours that are expected or required by the members of an organization. Kalbers and Cenken (2008) relate role ambiguity to the lack of confidence that an employee perceives of his or her responsibility. In another perspective, role ambiguity is said to occur when an insufficient amount of information is given to an individual to perform a role and is commonly seen as a condition when disagreement happens in the work of the community with little understanding on the employee's side of what are expected of them (Fisher \& Gitelson, 1983; Jackson \& Schuler, 1985).
In addition, role ambiguity is also defined as the occurrence of insufficient information pertaining to powers, authority and duties to perform one's role (Kahn, Wolfe, Snoek \& Rosenthal, 1964). Perhaps one of the famous definitions of role ambiguity after the work of Kahn et al. (1964) was given by Rizzo, House and Lirtzman (1970). They mentioned that role ambiguity occurred when one is not equipped with a good understanding of the job responsibilities and having little knowledge of what is expected in relation to job performance. On the other hand, role clarity occurs when an employee is clear about behavioural expectations, which assist in giving the necessary knowledge of what is considered as acceptable behaviour (Rizzo et al., 1970). Since the opposite end of role ambiguity is role clarity, one can only experience one or the other when work is performed (Rizzo et al., 1970).

In view of the potential effect of role ambiguity towards employee job performance, it had received a prominent position in many empirical researches (King \& King, 1990; Tubre \& Collins, 2000; Ortqvist \& Wincent, 2006). For instance, role ambiguity had been foundtodecreasejobperformance,satisfaction and commitment (Chang \& Chang, 2007). In addition, role ambiguity had also been linked to educational factors in a number of studies (e.g. Thompson, McNamara \& Hoyle, 1997; Wolverton, Wolverton \& Gmelch, 1999; Koustelios, Theodorakis \& Goulimaris, 2004). Thus, the following section will review the previous studies specifically on the relationship between role ambiguity and the job performance of employees.

\section{Exploring Role Ambiguity and Job Performance Link}

Reviews of past studies found limited empirical evidence between role ambiguity 
and performance (Singh, 1993). A metaanalysis based on the work of Jackson and Schuler (1985) by Tubre and Collins (2000) found that in order for an individual to carry out a task effectively, sufficient information is imperative. This is because when there is a lack of information regarding what is to be achieved, and the most effective work behaviour that can help the top management to achieve that will result in ineffective work performance. Although most research has found negative relationships between role ambiguity and job performance, the strength of association between role ambiguity and job performance varies widely according to the types of occupation and performance measure (Jackson \& Schuler, 1985).

Abramis (1994) provided evidence that role ambiguity resulted in the reduction of work performance. Besides that, research on job performance of the front-line service employees by Singh and Rhoads (1991) found that there were several types of role ambiguity such as those with regards for their superiors, the company, ethical issues, customers, co-workers, family and other managers. Knight, Kim and Crutsinger (2007), in their attempt to examine the causal relationship between role stress, customer orientation, selling orientation, and job performance of retail salespeople, revealed that role conflict and role ambiguity affected customer orientation while affecting job performance when mediated by customer orientation.

In addition, Behrman, Bigoness and Perreault (1981) revealed that there was a positive relationship between job performance and ambiguity concerning family expectation. On the other hand, the same study revealed that ambiguity regarding sales manager and customer expectations was negatively related to job performance. At the same time, the study also discovered that when there existed ambiguous managerial expectations a lower level of satisfaction was recorded. A similar effect was found by Kahn et al. (1964) as cited by Walker, Churchill and Ford (1975). When an employee experienced so much uncertainty about what was expected in performing a job, a high level of anxiety and tension would develop which in turn reduced job satisfaction and this could affect job performance.

Dubinsky, Michaels, Kotabe, Chae and HeeCheol (1992) carried out a study to compare whether role stressors such as role ambiguity and role conflict can influence work outcome among salespeople in the US, Japan and Korea. The findings revealed that role ambiguity was significantly negatively related to the job performance of the employees and there was no difference in the magnitude of the coefficients when comparing among the three sample nations. Based on those studies that found role ambiguity to be related to job performance, the relationship was found to be significantly negative (Kahn et al., 1964; House \& Rizzo, 1972; Zeithaml, Berry \& Parasuraman, 1988).

\section{Gaps in the Literature}

The existing empirical researches provided little support for the expected adverse effects of role ambiguity towards job performance. Though role ambiguity was found to have a negative relationship with job performance (Behrman \& Perreault, 1984; Lysonski \& Johnson, 1983), Jackson and Schuler's (1985) meta-analytic studies found that the effect of role ambiguity on job performance was rather weak and this was further supported by similar findings by Fisher and Gitelson (1983) 
and Berkowitz (1980). In addition, studies by Bagozzi (1978), Hampton, Dubinsky and Skinner (1986), and Szilagyi (1977) found no association between role ambiguity and job performance, which contradicted the result found by Bagozzi (1980) where role ambiguity was found to affect the job performance of employees. Past researches on the relationship between role ambiguity and job performance seem to develop mixed results. Since some studies found association while others found no association between role ambiguity and job performance (Michaels, Day \& Joachimsthaler, 1987; Wetzels, Ruyter \& Bloemer, 2000), a gap was created to re-examine the role of ambiguity in the context of the service sector SMEs in Malaysia. Therefore, this study hypothesizes that there is a significant relationship between role ambiguity and the job performance of employees.

\section{Methodology}

A mail survey was carried out to collect data from employees who are currently working the service sector SMEs who form the unit of analysis for this research. In order to determine the population of this study, reference was made to a sampling frame that was obtained from the SME business directory (SME Business Directory, 2011). The total number of service SMEs available in Malaysia is 5,527 as shown in Table1. Total elements for the entire population based on the sampling frame amounted to 27635 employees (non-owner/manager) which is based on the definition given by the central bank of Malaysia, in which a service SME will have a minimum of 5 to a maximum of 50 employees (Bank Negara Malaysia, 2005). Thus, the minimum required sample size as suggested by Krejcie and Morgan (1970), with a population of $\mathrm{N}=27635$ is 379 employees. A systematic random sampling was used to select 1,500 respondents (based on the response rate of $25 \%$ for mail survey in Malaysia ( Ismail \& King, 2005) in order to obtain the required minimum sample size of 379. Under the systematic random sampling technique, a sample is chosen by selecting a random starting point and then picking every $\mathrm{K}^{\text {th }}$ element in succession from the sampling frame (where $\mathrm{K}$ is the sampling interval). 300 SMEs in total were chosen under this technique $(1500 \div 5$ employees $)$. For this study, every $18^{\text {th }}$ firm was automatically selected from the list in the sampling. For example, the sample included the $18^{\text {th }}$ name, the $36^{\text {th }}, 54^{\text {th }}, 72^{\text {nd }}$ and so on and so forth. Thus, 300 firms (1,500 employees) were finally selected from the list of 5,527 SMEs.

Each variable was measured using a previously developed instrument with a 7-point Likert scale for all the measurements used ranging from (1) - strongly disagree to (7)-strongly agree. Job performance was adopted from William and Anderson (1991) with 6 items with reported reliability of .91 while role ambiguity was adopted from Rizzo et al. (1970) with 6 items with a reported reliability of between .78 to .81 , thus meeting the threshold value of Cronbach's alpha of .70 (Nunnally, 1978). In addition, 7 items were on demographic questions, which used ordinal and nominal scales on gender, age, ethnic, qualification, occupational sector, working experience and tenure of service. Pre-test of the measurements was conducted among 30 respondents working in the service sector SMEs in order to determine the reliability of the adopted measurement. Upon completion of the pre-test, the Cronbach's alpha value for job performance (after deletion of 2 items) was .87 and .74 for role ambiguity. 
Table 1

Number of Service SMEs (including ICT) in Malaysia as of March 2011

\begin{tabular}{lc}
\hline States & Number of service SMEs (including ICT) \\
\hline Perlis & 24 \\
Kedah & 205 \\
Perak & 267 \\
Penang & 351 \\
Kelantan & 115 \\
Trengganu & 142 \\
Pahang & 178 \\
Selangor & 1,686 \\
Wilayah Persekutuan KL & 1,248 \\
Wilayah Persekutuan Putrajaya & 24 \\
Wilayah Persekutuan Labuan & 20 \\
Melaka & 163 \\
Negeri Sembilan & 156 \\
Johor & 467 \\
Sabah & 243 \\
Sarawak & 238 \\
\hline Total & 5,527 \\
\hline
\end{tabular}

Source. SME Business Directory, 2011

\section{Findings}

Out of the 1,500 questionnaires distributed and after the screening process, 300 returned survey were usable for further analysis resulting in a $20 \%$ response rate. Since the data collected was less than the actual minimum required sample size of 379 , a nonresponse bias test was conducted. This test is to indentify whether there is a possibility that those who did not respond would have answered differently. Thus a non-response bias test was carried out on the 300 usable responses in which 180 responses that were obtained first were regarded as the first wave responses while the remaining 120 late respondents who formed the second wave responses were treated as non-respondents as according to the assumption by Armstrong and Overton (1977). Based on the t-test for equality of means, at $\mathrm{p}$ value $<.05$, no significant difference was found between those responses that were obtained from the first wave and those that were obtained from the second wave. Further data screening was carried out. Through the outlier test, the Mahalanobis $\mathrm{D}^{2}$ scores suggested five respondents treated as outliers be ignored. The variables were found to be normally distributed and hence 295 respondents were valid to be used for further analysis.

Table 2 shows the distribution of the respondents according to their profiles in 
the study. The majority of them were female (53.6\%) compared to male (46.4\%). Most of them were aged 19 to 30 years old $(46.2 \%)$ and 31 to 40 years old (30.5\%). More than a half were Chinese (58.0\%), compared to Malays (20.3\%) and Indians (14.9\%). The rest were other races, including Bumiputra from Sabah and Sarawak. The respondents were attached to various business sectors. Most of them were from education (14.9\%), restaurant (14.6\%) and professional services $(14.2 \%)$. Only $11.2 \%$ of the respondents had worked for less than 1 year. The majority of the respondents had finished their tertiary education: diploma (21.7\%), bachelor degree $(30.5 \%)$ and postgraduate $(9.8 \%)$.

Table 2

Background of the Respondents

Frequency

Percentage

Gender

Male

Female

Age

Under 19

19 to 30

145

31 to 40

41 to 50

Above 50

Ethnic

Malay

Indian

Bumiputra from Sabah or Sarawak

Others

Business Sector

Retailers

Wholesalers

Transport \& equipment

Professional services

Consultancy services

Education

Hotel

Computer services and communication

Restaurants
137

158

15 


\begin{tabular}{lcc}
\hline & Frequency & Percentage \\
\hline Selected services & 21 & 7.1 \\
Financial services & 11 & 3.7 \\
Real estate activities & 11 & 3.7 \\
Health & 12 & 4.1 \\
Working experience & & \\
$<1$ year & 33 & 11.2 \\
1 to 5 years & 120 & 40.7 \\
6 to 10 years & 70 & 23.7 \\
$>10$ years & 72 & 24.4 \\
Education & & \\
SRP/PMR or below & 35 & 11.9 \\
SPM/MCE/O-Level & 52 & 17.6 \\
STPM/HSC/A-Level & 25 & 8.5 \\
Diploma Level & 64 & 21.7 \\
First Degree & 90 & 30.5 \\
Postgraduate & 29 & 9.8 \\
\hline
\end{tabular}

Factor analysis was utilized to test the construct validity of the measurements for this study. Suitability of using factor analysis as a tool for testing construct validity was determined through Kaiser-Meyer-Olkin (KMO) measure of sampling adequacy and the Barttlet's Test of Sphericity. Therefore, if the KMO values are greater than .60 (Coakes, Steed \& Ong, 2009), and the Bartlett's test of sphericity is large and significant $(\mathrm{p}<.05)$ (Hair, Black, Babin, Anderson \& Tatham, 2006), factorability is then considered as possible. Once factor analysis is carried out, items with factor loading that is greater than .30 will be used to represent a factor since it is regarded as the threshold to meet the minimal level for interpretation of structure (Hair et al., 2006). Thus, factor analysis was carried out on all the variables used in this study.

Table 3 presents the result of factor analysis for job performance. Items were chosen to identify a factor with loadings greater than .30 based on the guideline by Hair et al. (2006). According to Kline (1994), factor loading that is greater than .60 can be considered as high while any factor loading that is greater than 0.3 is regarded as moderately high. The factor loading were all found to be greater than 0.6 indicating good correlation between the items and the factor grouping they belonged to. Thus, job performance had all four questions loaded onto a single factor with eigenvalue of more than 1.0. The single factor extracted $71.13 \%$ of the total variance in response. At the same time, a scree plot also proposed a single factor solution (see Figure 1).

Role ambiguity had all six questions loaded onto a single factor with eigenvalue of more than 1.0. The single factor extracted $61.84 \%$ of the total variance in response. The result is shown in Table 3 . The scree plot for role ambiguity also suggested a single factor solution (see Figure 2). 
Table 3

Summary of Factor Loading for Job Performance

\begin{tabular}{lc}
\hline \multicolumn{1}{c}{ Question } & Component \\
\cline { 2 - 2 } JP1 completes assigned duties & 1 \\
JP2 fulfils responsibilities according to job descriptions & 0.87 \\
JP3 is able to perform as expected & 0.88 \\
JP4 meets the formal performance standards & 0.85 \\
Eigenvalues & 0.77 \\
Percentage of variance explained $=71.13 \%$ & 2.85 \\
KMO =0.81 & \\
Bartlett's Test of Sphericity: & \\
Approx. Chi-Square $=562.51$ & \\
df= 6 & \\
Sig $=.000$ &
\end{tabular}

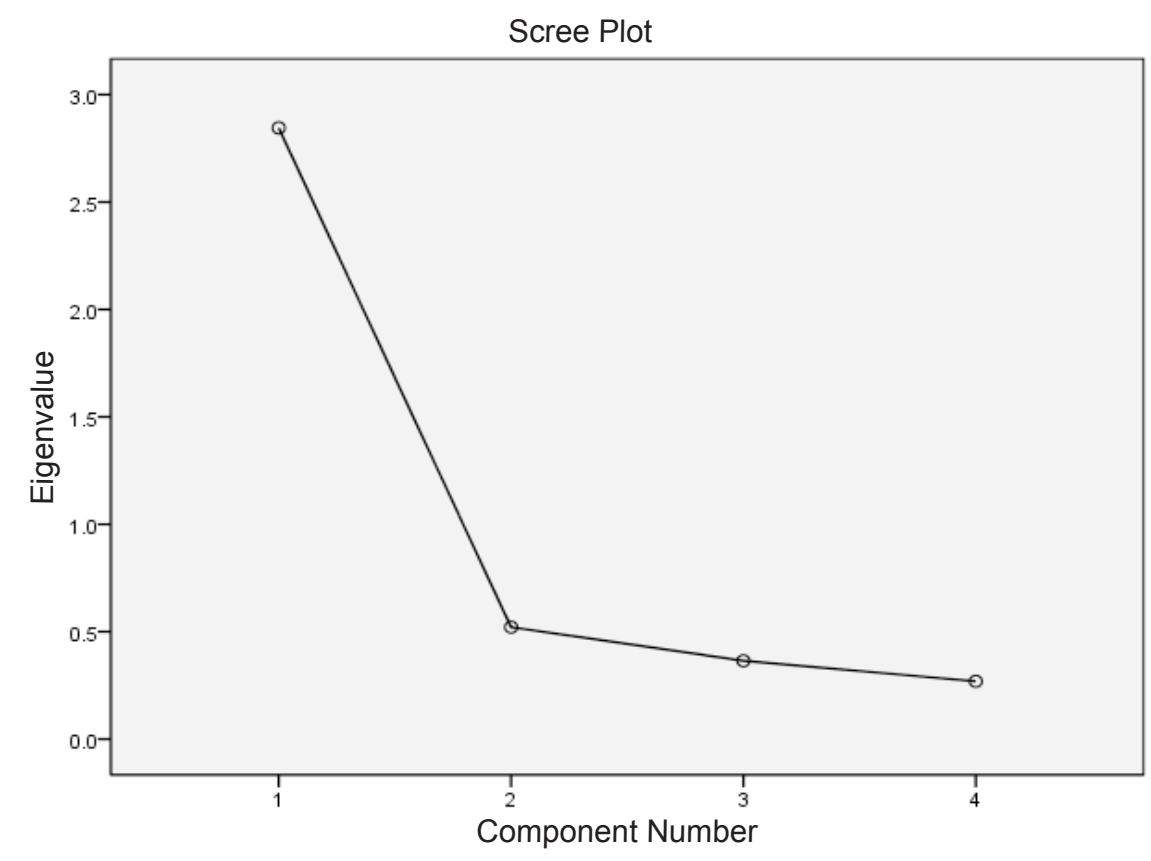

Figure 1. Scree plot for job performance 
Table 3

Summary of Factor Loading for Role Ambiguity

Questions

Component

1

RA1 certain about job authority

0.67

RA2 clear goals and objectives for job

0.84

RA3 have divided time properly

0.78

RA4 know about responsibilities

0.83

RA5 know about what is expected

0.82

RA6 explanations given are clear

0.77

Eigenvalues

Percentage of variance explained $=61.84 \%$

$\mathrm{KMO}=0.90$

Bartlett's Test of sphericity:

Approx. Chi-Square $=791.71$

$\mathrm{df}=15$

Sig $=.000$

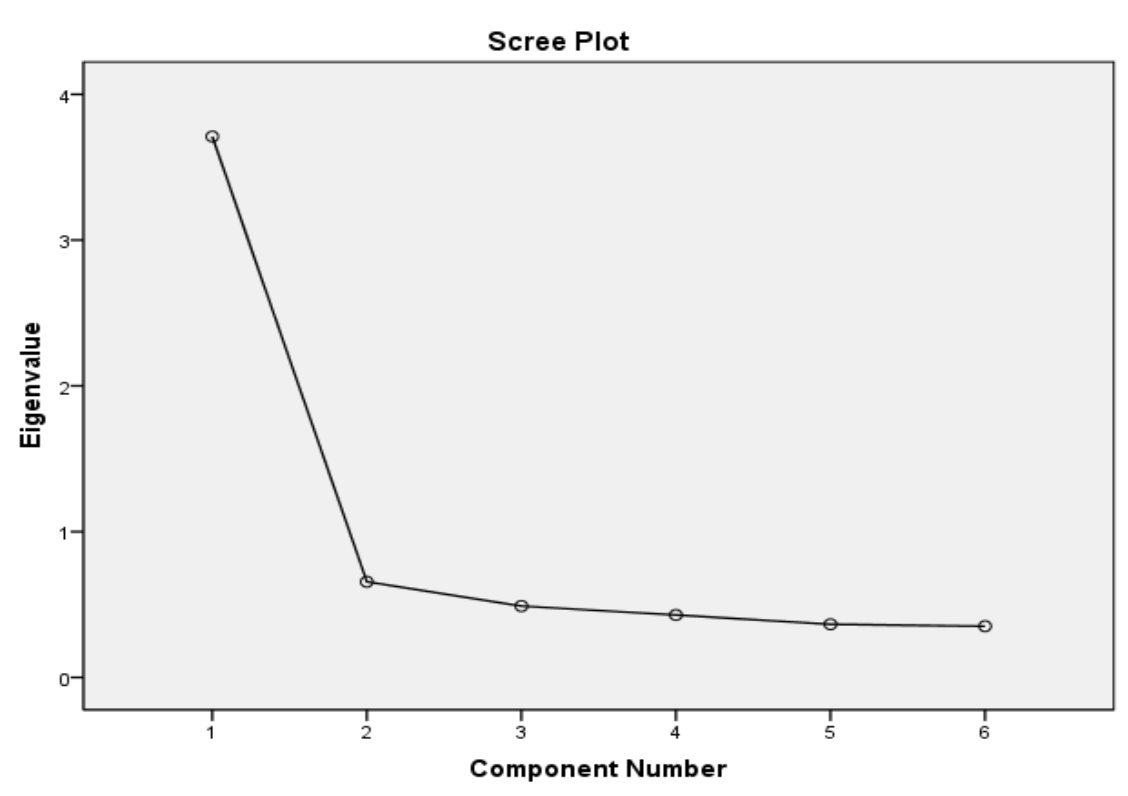

Figure 2. Scree plot for role ambiguity 
Table 4 presents the inter-correlations among all the variables in this study. The level of significance was at $5 \%(.05)$ which is a generally accepted conventional level in social sciences research (Sekaran \& Bougie, 2009). The correlation coefficient (r) indicates the strength of the association between any two metric variables (Hair et al., 2006). The sign (+ or -) indicates the direction of the relationship with a value that ranges between +1.0 to -1.0 . The value +1.0 indicates a perfect positive relationship, 0 indicates no relationship and -1.0 indicates a perfect negative or reverse relationship (Hair et al., 2006). Thus in testing the hypotheses, null hypotheses will be rejected if the significance $\mathrm{p}$ value is less than .05 which indirectly means the alternate hypotheses will be accepted, while the opposite will take place should the significance $\mathrm{p}$ value be greater than .05 . It is concluded that there is a significant relationship between job performance and role ambiguity $(\mathrm{r}=-0.686$, $\mathrm{p}<0.01)$. According to Davis (1971), this relationship is strong when the ' $r$ ' ranges from 0.50 to 0.69 . Thus, the hypothesis of this study is strongly supported.

\section{Table 4}

\section{Correlation Matrix of the Variables}

\begin{tabular}{llcc}
\hline & & Job performance & Role ambiguity \\
\hline 1. Job performance & Pearson Correlation & 1 & $-.69^{* *}$ \\
& Sig. (2-tailed) & & 0 \\
& $\mathrm{~N}$ & 295 & 295 \\
2. Role ambiguity & Pearson Correlation & $-.69^{* *}$ & 1 \\
& Sig. (2-tailed) & 0 & \\
& $\mathrm{~N}$ & 295 & 295 \\
\hline
\end{tabular}

**. Correlation is significant at the 0.01 level (2-tailed).

\section{Conclusions}

This study contributes to the present literature on SMEs in Malaysia specifically in the context of service sector SMEs, which have not received much attention. The knowledge obtained can assist employers in developing strategies on how they can redesign the job of employees in order to assist them to perform better. Thus, this study is timely, as evidence from past research has shown that a factor such as role ambiguity is important in the service sector setting. Role theory, as expounded by Kahn et al. (1964) states that role ambiguity will result in a job holder engaging in a coping behaviour (e.g. searching for more information) in an attempt to solve unclear tasks in a move to overcome stress which in turn will distort the reality of job requirements. This will then lead to a person feeling dissatisfied with his role, experiencing anxiety and thus performing less effectively.

The need to study role ambiguity arises because in any service sector setting, an 
employee who is able to understand what his or her role is in the organization is likely to perform well in his or her job when dealing with customers (Anderson, 2006). The result of this study supports past researches that found role ambiguity to have a significant negative relationship with the job performance of employees (e.g. Kahn et al., 1964; Lysonski \& Johnson, 1983; Jackson \& Schuler, Behrman \& Perreault, 1984; Singh, 1993; Bhuian, Merguc \& Borsboom, 2005; Chang \& Chang, 2007). In other words, when the level of role ambiguity increases, the level of job performance of employees will reduce as employees will not be able to cope with given tasks and thus perform less effectively. The reason for this finding can be explained by the fact that employees in a service setting are particularly susceptible to role ambiguity especially those in SMEs context as they generally receive little training and work with minimal supervision (Dubinsky \& Mattson, 1979). Small firms tend to have less formal human resource management (HRM) practices, thus this tendency was also extended in their training policy as well (Price, 1994). Furthermore, SMEs shorter lines of communication, problems being solved faster and ease of readjustment may also be the reasons behind this informal practice (Price, 1994).

Additionally, researches on SMEs in Malaysia are quite limited to the performance of SME firms rather than looking at the individuals' performance (e.g. Hashim, 2000; Sohail \& Hoong,2003;Alam\&Ahsan,2007; Jamaludin $\&$ Hasun, 2007). Therefore, this study will contribute to the dearth of research in relation to the job performance of employees. At the same time, researches on the job performance of employees that work in the service sector in Malaysia were conducted mainly on the public sector employees (e.g. Azmi, 2010) which created an insufficiency of studies on the service sector SMEs. Therefore, through this research, employees especially those in the service sector SMEs were given attention to help in understanding the reasons behind poor performance that affects the level of productivity. This study also suggests future research to cover both the service and the manufacturing sector employees so that comparisons can be done in order to see whether employees in the manufacturing sector experience similar conditions like their counterparts in the services sector. In addition, in order to identify specifically the approaches that can be used to enhance the job performance of those employees, it is suggested that future research to be conducted on specific areas of the business sector. Thus, future research may consider specific business sectors such as education, hotel, retailing, and business services which are under the twelve key areas of the national transformation programme (NKEAs) (PEMANDU, 2011), so that more specific strategies can be designed to meet the needs of the employees of the specific sectors.

\section{References}

Abdullah, F., Hamali, J., Deen, A. R., Saban, G., \& Abdurahman, A. Z. A. (2009). Developing a framework of success of Bumiputera entrepreneurs. Journal of Enterprising Communities: People and Places in the Global Economy, 3(1), 8-24.

Abramis, D. J. (1994). Work role ambiguity, job satisfaction, and job performance: Meta-analyses and review.Psychological Reports, 75, 1411-1433.

Ackerman, P. L.(1987).Individual differences in skill learning: An integration of psychometric and information processing perspective. Psychological Bulletin, 102, 3-27. 
Al-Ahmadi, H. (2009). Factors affecting performance of hospital nurses in Riyadh Region, Saudi Arabia. International Journal of Health Care Quality Assurance, 22(1), 40-54.

Alam, S. S., \& Ahsan, M. N. (2007). ICT adoption in Malaysian SMEs from services sectors: Preliminary findings. Journal of Internet Banking and Commerce, 12(3).

Alasadi, R.,\& Abdelrahim,A.(2008). Analysis of small business performance in Syria. Education, Business and Society: Contemporary Middle Eastern Issues, 1(1), 50-62.

Anderson, J. R. (2006). Managing employees in the service sector: A literature review and conceptual development. Journal of Business and Psychology, 20(4).

Aris, N. M. (2007). SMEs: Building blocks for economic growth. Journal of the Department of Statistics Malaysia, 1, $1-14$.

Armstrong, J. S., Overton, T. S. (1977). Estimating non-response bias in mail surveys. Journal of Marketing Research, 24, 396-402.

Azmi, I. A. G. (2010). Competency-based human resource practices in Malaysian public sector organisations. African Journal of Business Management, 4(2), 235-241.

Babin, B.J., \& Boles, J.S.(1996). The effects of perceived co-worker involvement and supervisor support on service provider role stress, performance and job satisfaction. Journal of Retailing, 72(1), 57-75.

Bagozzi, R. P. (1980). The nature and causes of self-esteem, performance and satisfaction in the sales force: A structural approach.Journal of Business, 53, 315-333.
Bagozzi,R.P.(1978). Sales force performance and satisfaction as a function of individual difference, interpersonal, and situational factors. Journal of Marketing Research, 15 (November), 517-531.

Bank Negara Malaysia. (2005). Small and medium enterprise (SME) annual report 2005. Kuala Lumpur: Bank Negara Malaysia.

Beauchamp, M. B., Bray, S. R., Eys, M. A., \& Carron, A. V. (2005). Leadership behaviours and multidimensional role ambiguity perceptions in team sports. Small Group Research, 36(1), 5-20.

Behrman, D. N., \& Perreault, W. D. (1984). A role stress model of the performance and satisfaction of industrial salespersons. Journal of Marketing, 48, 9-21.

Behrman, D. N., Bigoness, W. J., \& Perreault, W. D. (1981). Job related ambiguity and their consequences upon salespersons' job satisfaction and performance. Management Science, 27(11), 1246-1260.

Berkowitz, E. N. (1980). Role theory, attitudinal constructs and actual performance: A measurement issue. Journal of Applied Psychology, 65, 240-245.

Bhuian, S. N., Menguc., B., \& Borsboom, R. (2005). Stressors and job outcomes in sales: A triphasic model versus a linear-quadratic-interactive model. Journal of Business Research, 58, 141-50.

Bohlander, G., Snell, S., \& Sherman, A. (2001). Managing human resources. Cincinnati, Ohio: South-Western College Publishing.

Borman, W. C., Hanson, M. A., \& Hedge, J. W. (1997). Personnel selection. Annual Review of Psychology, 48, 299-337.

Brief, A. P., \& Aldag, R. J. (1976). Correlates of role indices. Journal of Applied Psychology, 61, 468-72. 
Busch, P., \& Bush, R. F. (1978). Women contrasted to men in the industrial salesforce: Job satisfaction, values, role clarity, performance, and propensity to leave. Journal of Marketing Research, 438-448.

Campbell, J. P. (1990). Modeling the performance prediction problem in industrial and organizational psychology. In M. D. Dunnette \& L. M. Hough (Eds.), Handbook of industrial and organizational psychology (Vol.1, pp. 687-732). Palo Alto: Consulting Psychologists Press.

Campbell, J. P., Gasser, M. B., \& Oswald, F. L. (1996). The substantive nature of job performance variability. In K. R. Murphy (Ed.), Individual differences and behaviour in organisations (pp. 258-299). San Francisco: JosseyBass.

Campbell, J. P., McCloy, R. A., Oppler, S. H., \& Sager, C. E. (1993). A theory of performance. In E. Schmitt, W. C. Borman \& Associates (Eds.), Personnel selection in organizations (pp. 35-70). San Francisco: JosseyBass.

Caniels, M. C. J., \& Romijn, H. A. (2005). What works, and why, in business services provision for SME: Insights from evolutionary theory. Managing Service Quality, 15(6), 591-608.

Chang, T. Y., \& Chang, Y. L. (2007). Relationship between role stress and job performance in salespeople employed by travel agents in Taiwan. International Journal of Stress Management, 14, 211-223.

Che Ros, R., Kumar, N., \& Lim, L. Y., (2006).Entrepreneurs'success factors and escalation of small and mediumsized enterprises in Malaysia. Journal of Social Sciences, 2(3), 74-80.
Coakes, S. J., Steed, L., \& Ong, C. (2009). SPSS 16.0 for windows: Analysis without anguish. Australia: John Wiley and Sons.

D’Amato, A., \& Zijlstra, F. R. H. (2008). Psychological climate and individual factors as antecedents of work outcomes. European Journal of Work and Organisational Psychology, 17(1), 33-54.

Davis, J. A. (1971). Elementary Survey Analysis. Englewood Cliffs: Prentice Hall.

Department of Statistics. (2006). Census of establishments and enterprises 2005. Preliminary report - profile of small and medium enterprises.

Dessler, G. (2011). Human resource management (12th ed.). USA: Prentice-Hall.

Dubinsky, A. J., Michaels, R., Kotabe, M., Lim, C. U., \& Moon, H. (1992). Influence of role stress on industrial salespeople's work outcomes in the United States. Japan and Korea. Journal of International Business Studies, 23(1), 77-99.

Eysenck, M. (1998). Psychology: An integrated approach. New York: Addison-Wesley Longman.

Fisher, C. D., \& Gitelson, R. (1983). A meta-analysis of the correlates of role conflict and ambiguity. Journal of Applied Psychology, 68(2), 320333.

Frogner, M. L. (2002). Skills shortages. Labour Market Trends, January, 17-27.

Galagan, P. A. (1997). Strategic planning is back. Training and Development, 51(4), 32-37.

Green, F., Machin, S., \& Wilkinson, D. (1998).The meaning and determinants of skills shortages. Oxford Bulletin of Economics and Statistics, 60(2), 165-87. 
Grubb, A. D. (1999). The effect of tenure and job complexity on the contributions of task and contextual performance to overall performance (Unpublished doctoral dissertation). Retrieved from ProQuest Dissertations and Theses database. (AAT 9945766).

Gu, Z., \& Chi, R. S. S. (2009). Drivers of job satisfaction as related to work performance in Macao casino hotels: An investigation based on employee survey. International Journal of Contemporary Hospitality Management, 21(5), 561-578.

Hair, J. F., Black, W. C., Babin, B. J., Anderson, R. E., \& Tatham, R. L. (2006). Multivariate data analysis (6th ed.). New Jersey: Pearson Prentice Hall.

Hall, C. (2002). Profile of SMEs and SME issues in APEC 1999-2000. Mexico: APEC SME Ministerial Meeting.

Hall, M. (2008). The effect of comprehensive performance measurement systems on role clarity, psychological empowerment and managerial performance.Accounting, Organisations and Society, 33, 141163.

Hampton, R., Dubinsky, A. J., \& Skinner, S. J. (1986). A model of sales supervisor leadership behaviours and retail salespersons job-related outcomes. Journal of the Academy of Marketing Science, 14, 33-42.

Hamzah, A., \& Ho, S. (1994).TQM training for small and medium industries in Malaysia. Training for Quality, 2(2), 27-35.

Hashim, M. K. (2000). SMEs in Malaysia: Past, present and future. Malaysian Management Review, 35(1), 22-32.

House, R. J., \& Rizzo, J. R. (1972). Role conflict and ambiguity as critical variables in a model of organizational behaviour. Organizational Behaviour and Human Performance, 1, 467505.

Ilgen, D. R., \& Hollenbeck, J. R. (1991). The structure of work: Job design and roles. In M. D. Dunnette \& L. M. Hough, (Eds.), Handbook of industrial and organizational psychology (pp. 165-207). Palo Alto, CA: Consulting Psychologist Press.

Ivancevich, J. M., \& Donnelly, J. H. (1974). A study of role clarity and need for clarity for three occupational groups. The Academy of Management Journal, 17(1), 28-36.

Jackson, S. E., \& Schuler, R. S. (1985). A meta-analysis and conceptual critique of research on role ambiguity and role conflict in work settings. Organizational Behaviour and Human Decision Processes, 36, 16-78

Jamaludin, Z., \& Hasun, F. M. (2007). The importance of staff training to the SMEs' performance. Kajang: Selangor International Islamic University College.

Jaramilloa, F., Mulki, J. P., \& Marshall, G. W. (2005). A meta-analysis of the relationship between organizational commitment and salesperson job performance: 25 years of research. Journal of Business Research, 58, 705-714.

Kahn, R. L., Wolfe, D. M., Quinn, R. P., Snoek, J. D., \& Rosenthal, R. A. (1964). Occupational stress: Studies in role conflict and ambiguity. New York: John Wiley \& Sons.

Kalbers, L. P., \& Cenker, W. J. (2008). The impact of exercised responsibility, experience, autonomy, and role ambiguity on job performance in public accounting. Journal of Managerial Issues, 20(3), 327-347.

Karatepe, O. M., Uludag, O., Menevis, I., Hadzimehmedagic, L., \& Baddar, L. (2006). The effects of selected 
individual characteristics on frontline employee performance and job satisfaction. Tourism Management, 27, 547-560.

King, L. A., \& King, D. W. (1990). Role conflict and role ambiguity: A critical assessment of construct validity. Psychological Bulletin, 107, 48-64

Kline, P. (1994). An easy guide to factor analysis. London: Routledge.

Knight, D. K., Kim, H. J., \& Crutsinger, C. (2007). Examining the effects of role stress on customer orientation and job performance of retail salespeople. International Journal of Retail and Distribution Management, 35(5), 381-392.

Knowles, P. A., Grove, S. J., \& Pickett, G. M. (1992). The role of mood in consumer responses to service encounters: Review and propositions. Winter Educators Conference, American Marketing Association, Chicago, IL.

Koustelios, A., Theodorakis, N., \& Goulimaris,D.(2004). Role ambiguity, role conflict and job satisfaction among physical education teachers in Greece. International Journal of Educational Management, 18, 87-92.

Krejcie,R.,\&Morgan,D.(1970).Determining sample size for research activities. Educational and Psychological Measurement, 30, 607-610.

Lado, A. A., \& Wilson, C. M. (1994). Human resource systems and sustained competitive advantage: A competencybased perspective. Academy of Management Review, 19, 699-727.

Lang, J., Thomas, J. L., Bliese, P. D., \& Adler, A. B. (2007). Job demands and job performance: The mediating effect of psychological and physical strain and the moderating effect of role clarity. Journal of Occupational Health Psychology, 12(2), 116-124.
Lysonski, S. J., \& Eugene M. J. (1983). The sales manager as a boundary spanner: A role theory analysis. Journal of Personal Selling and Sales Management, 3, 8-21.

Mahmood, R., \& Rahman, G.A. (2007). How bank managers assess small business borrowers? Malaysian Management Review, 42(1), 43-53.

Mathis, R.L., \& Jackson, J.H. (2000). Human resource management. Australia: South-Western: College Publishing.

Michaels, R.E., Day, R.L., \& Joachimsthaler, E. A. (1987). Role stress among industrial buyers: An integrative model. Journal of Marketing, 51(2), 28-45.

Moha, A. (1999). Small and medium enterprises in Malaysia: Policy issues and challenges. Vermont: Ashgate.

Motowidlo, S. J., Borman, W. C., \& Schmit, M. J. (1997). A theory of individual differences in task and contextual performance. Human Performance, $10,71-83$.

Mukherjee, A., \& Maholtra, N. (2006). Does role clarity explain employeeperceived service quality? A study of antecedents and consequences in call centres. International Journal of Service Industry Management, 17(5), 444-473.

Murphy, K. R. (1989). Is the relationship between cognitive ability and job performance stable over time? Human Performance, 2, 183-200.

Ndubisi, N. O. (2008). Small and medium enterprises in the Pacific rim. Kuala Lumpur: Arah Publications.

Ng, T. W. H., \& Feldman, D. C. (2009). How broadly does education contribute to job performance? Personnel Psychology, 62(1), 89.

Nunnally, J. C. (1978). Psychometric theory (2nd ed.). New York: McGraw-Hill. 
Ortqvist, D., \& Wincent, J. (2006). Prominent consequences of role stress: A meta-analytic review. International Journal of Stress Management, 13, 399-422.

Osman,I.,Ho, T.C.F., \& Galan,M.C. (2011). Are human resource departments really important? An empirical study on Malaysian small and medium enterprises (SMEs) in the service sector. International Journal of Business and Management, 6(2), 147-153.

PEMANDU (2011). NKEA: National key economic area. Retrieved from http://etp.pemandu.gov

Piercy, N. F., Cravens D. W., \& Morgan, N. (1998) Sales force performance and behaviour based management pressures in business-to-business sales organisation. European Journal of Marketing, 1(32), 79-100.

Price, L. (1994). Poor personnel practice in the hotel and catering industry: Does it matter? Human Resource Management Journal, 4(4), 44-62.

Price, L. L., Arnould, E. J., \& Tierney, P. (1995). Going to extremes: Managing service encounters and assessing provider performance. Journal of Marketing, 59, 83-97.

Ramayah, T., \& Koay, P. L. (2002). An exploratory study of internet banking in Malaysia. The proceedings of The 3rd International Conference on Management of Innovation and Technology (ICMIT '02 \& ISMOT '02), Hangzhou City, P. R. China.

Rizzo, J. R., House, R. J., \& Lirtzman, S. I. (1970). Role conflict and ambiguity in complex organizations. Administrative Science Quarterly, 15, 150-63.

Saleh, A. S., \& Ndubisi, N. O. (2006). SME development in Malaysia: Domestic and global challenges. Wollongong: University of Wollongong.

Sarmiento, R., \& Beale, J. (2007). Determinants of performance amongst shop-floor employees. Management Research News, 30(12), 915-927.

Schmitt, N., \& Chan, D. (1998). Personal selection: A theoretical approach. Thousand Oaks, CA: Sage Publications.

Sekaran, U., \& Bougie, R. (2009). Research methods for business (5th ed.). West Sussex UK: John Wiley \& Sons.

Sin, K. S. (2010). The success stories of Malaysian SMEs in promoting and penetrating global markets through business competitiveness strategies. Asia Research Centre, CBS, Copenhagen Discussion Papers 2010-2033.

Singh, J. (1993). Boundary role ambiguity: Facets, determinants, and impacts. Journal of Marketing, 57, 11-31.

Singh, J., \& Rhoads, G. K. (1991). Boundary role ambiguity in marketing-oriented positions: A multidimensional, multifaceted operationalization. Journal of Marketing Research, 28, 328-38.

SME Annual Report. (2007). Retrieved from http://www.smeinfo.com.my

SME Business Directory. (2011). Retrieved from www.https://secure.smeinfo. com

SMIDEC (2002). SMI development plan (2001-2005). Kuala Lumpur: Percetakan Nasional Malaysia.

Sohail, M. S., \& Hoong, T. B. (2003). TQM practices and organisational performances of SMEs in Malaysia: Some empirical observations. Benchmarking: An International Journal, 10(1), 37-53. 
Stuti, K. IAS. (2005). Overcoming barriers to innovation for Indian SMEs. New Delhi: Ministry of Small Scale Industries India.

Szilagyi, A. D. (1977). An empirical test of causal inference between role perceptions, satisfaction with work, performance and organization level. Personnel Psychology, 30, 375-388.

Thompson, D. P., McNamara, J. F., \& Hoyle, J. R. (1997). Job satisfaction in educational organizations: A synthesis of research findings. Educational Administration Quarterly, 33, 7-37

Ting, O. K. (2004). SMEs in Malaysia: Pivot points for change. Retrieved from http://www.mca.org.my

Tomaka, L. A. (2001). Workforce development in the Midwestern region. Spectrum, 74, 26-27.

Tubre, T., \& Collins, J. (2000). Jackson and Schuler (1985) revisited: A meta-analysis of the relationship between role ambiguity, role conflict and job performance. Journal of Management, 26, 155-169.

United Parcel Services. (2005). UPS reveals asia business monitor survey findings. Retrieved from http://www. ups.com

Van Scotter, J. R., Motowidlo, S. J., \& Cross, T. C. (2000). Effects of task performance and contextual performance on systemic rewards. Journal of Applied Psychology, 85, 526-535.

Varca, P. E. (2002). Service representatives, job control, and blue-collar blues. Journal of Services Marketing, 15, 257-69.

Walker, O.C., Churchill, G.A., \& Ford, N.M. (1975). Organizational determinants of the industrial salesman's role conflict and ambiguity. Journal of Marketing, 30, 32-39.

Wang, S. D. (2003). The implications of e-financing: Implications for SMEs. Bulletin on Asia-Pacific Perspective 2003/2004, United Nations.

Wener, R. E. (1985). The environmental psychology of service encounters. In J. A. Czepiel, M. R. Solomon \& C. F. Surprenant (Eds.), The service encounter (pp. 101-12).Lexington Books: Lexington, MA.

Wetzels, M., Ruyter, D. K., \& Bloemer, J. (2000). Antecedents and consequences of role stress of retail sales persons. Journal of Retailing and Consumer Services, 7, 65-75.

Williams, L., \& Anderson, S. (1991). Job satisfaction and organisational commitment as predictors of organisational citizenship and in-role behaviours. Journal of Management, 17, 601-617.

Wolverton, M., Wolverton, M. L., \& Gmelch, W. H. (1999). The impact of role conflict and ambiguity on academic deans. The Journal of Higher Education, 70, 80-106.

Wyer, P., \& Mason. J. (1999). Empowerment in small businesses. Participation \& Empowerment: An International Journal, 7(7), 180-193.

Yogeesvaran, K. (2005). Regional conference on investment climate and competitiveness in East Asia addressing skills gap: Malaysian case. Economic Planning Unit.

Zeithaml, V. A., Berry, L. L., \& Parasuraman, A. (1988). Communication and control processes in the delivery of servicequality. Journal of Marketing , 52(2), 35-48. 